\title{
A Teaching Material Based on Science, Environment, Technology, and Society to Improve Student's Critical Thinking Skills: Synchronous and Asynchronous Learning During Covid-19 Pandemic
}

\author{
Aziza Syaila Amilyana1, Tjandra Kirana M. Sjaifullah Noer2, Raharjo ${ }^{3}$ \\ 1,2,3 State University of Surabaya, Surabaya, Indonesia
}

\begin{tabular}{|c|c|}
\hline 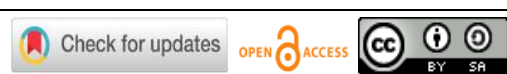 & DOI : https://doi.org/10.46245/ijorer.v2i4.109 \\
\hline Sections Info & ABSTRACT \\
\hline $\begin{array}{l}\text { Article history: } \\
\text { Submitted: March 8, } 2021 \\
\text { Final Revised: May 22, } 2021 \\
\text { Accepted: June 08, 2021 } \\
\text { Published Online: July 31, } 2021\end{array}$ & $\begin{array}{l}\text { Student's critical thinking has not been maximally train in learning, learning } \\
\text { activities are only memorizing demands of passing the assessment. Students } \\
\text { are less understand, build, and criticize arguments about a problem, especially } \\
\text { in science learning. This is the introduction for the development of teaching } \\
\text { materials based on Science, Environment, Technology, and Society (SETS). }\end{array}$ \\
\hline $\begin{array}{l}\text { Keywords: } \\
\text { Learning material } \\
\text { SETS } \\
\text { Critical thinking } \\
\text { Synchronous and asynchronous } \\
\text { learning }\end{array}$ & $\begin{array}{l}\text { This study aims to determine how the feasibility of science teaching materials } \\
\text { based on SETS in ecosystem materials to improve the critical thinking skills of } \\
\text { grade } 5 \text { students. This type of research is research and development (Research } \\
\text { and Development) with a 4D model. This research was conducted online } \\
\text { using Microsoft Teams which was carried out synchronously and } \\
\text { asynchronously due to the Covid-19 pandemic. The data collection technique } \\
\text { is the expert validation stage, the implementation of learning observation } \\
\text { sheets, critical thinking tests (pretest and posttest), and student response } \\
\text { questionnaires and then analyzed using quantitative and descriptive } \\
\text { techniques. The results show that: (1) teaching materials were in the feasible } \\
\text { category with an average of 3.4, (2) practical based on observations of the } \\
\text { implementation of learning with an average of } 93 \% \text { and the categories are } \\
\text { good, and } 95 \% \text { of the student activity was active, ( } 3 \text { ) effective based on the } \\
\text { acquisition of N-gain on the critical thinking test is } 0.77 \text { (high category), and } \\
\text { the student response questionnaire that is } 97 \% \text { very good category. This } \\
\text { teaching material based on SETS is expected to improve students' critical } \\
\text { thinking skills, in this study students can be categorized as having high critical } \\
\text { thinking skills. }\end{array}$ \\
\hline
\end{tabular}

\section{INTRODUCTION}

The massive use and development of information communication technology have changed the lifestyle of humans, the demands of doing something fast and satisfying results make people have to work smartly in solving problems, including in the field of education. In Natural Sciences the process of technological development begins with this intelligent thinking. Science is a human effort to think about something that occurs in the universe with tested thinking and reasoning, according to procedures to generate logical and measurable conclusions. Natural Science learning in SD is aimed at developing potential in students by facilitating students with problems that they want to solve, motivating students to curiosity, developing reasoning skills through asking questions and the desire to find evidence for answers to natural phenomena that occur, and developing scientific ways of thinking (Susanto, 2016). Therefore, teachers must pay attention to important aspects by involving students actively in learning activities under everyday life and solving problems. Based on some of these opinions, models teaching science that has been implemented since the beginning until now is still conventional or teacher centered, where the delivery system is dominated by teachers, and the communication process is one-way (Muakhirin, 2014). 
A Teaching Material Based on Science, Environment, Technology, and Society to Improve Student's Critical Thinking Skills: Synchronous and Asynchronous Learning During Covid-19 Pandemic

Thinking is the main thing in human life and psychological activities, and in an activity, it is not uncommon to encounter various problems that come, therefore thinking functions to unravel problems, make decisions, and provide reasons. To solve problems properly, students' ability is needed by practicing their critical thinking skills. This corresponds to one of the goals of the national education of the Indonesian nation is to educate the nation's life as stated in the preamble to the fourth paragraph of the 1945 Constitution. Smart to provide solutions and solve problems. According to Bassham G in Nur et al (2013) that critical thinking is very important for students because it can help students build, understand and criticize an opinion. At the time of basic education, students are required to plan small steps before finally choosing higher-order thinking skills. For this reason, when children have the opportunity to use higher-level skills, children begin to be able to distinguish between truth and untruth, reality and appearance, opinions and facts, beliefs, and knowledge. Also, children who are trained to think critically will be tough, independent, and become good problem solvers.

Based on preliminary observations and interviews conducted by researchers in October 2019 at Manukan Kulon State Elementary School Surabaya, it was found that the implementation of learning did not encourage the emergence of critical thinking skills, exploration of conventional teaching skills in the form of one-way transfer from teachers to students. Lack of active, direct activities that involve the physical and five senses in developing learning materials. The facilities for the critical thinking skills of class $\mathrm{V}$ students have not been trained as much as possible by student development. However, from the indicators of critical thinking skills, students only memorize to meet the demands of passing the daily assessment as well as the final semester assessment. In teaching and learning activities, there are not many teachers who facilitate student activities that support critical thinking. This is found in teacher learning activities only focused on explaining the material and ends with doing exercises from the material that students memorize. This is in line with opinion Firdaus et al (2020) factors causing science learning in SD hasn't been able to provide results like that is expected that is based on the curriculum, the use of an inappropriate approach or creation or selection of inner media learning.

One of the supporters of learning is the use of teaching materials that are very important for classroom learning. In practice, the teaching and learning process only uses thematic textbooks. Reviewing the analysis of student thematic books from the government used in elementary schools as a whole includes competencies that must be mastered by students, has presented integrated learning with other subjects, there are a project-based activity sheet and literacy at the end of the book page. However, there are only a few activities for science, the lack of integration with real objects that can provide students with direct experiences. According to Rasmawan (2020) In the teaching materials, they provide problems that will be solved and are directly related to their daily lives, such as critical thinking exercises by presenting issues that are appropriate to their environment and the task of projects to purify peat water in their environment. The relationship of relevance and the emergence of problems that are directly related to everyday life can make students actively involved in real situations and can cause students to better understand what they are learning and trying to solve. According to Syofyan et al (2019) Teaching materials or learning materials are all things that become 
A Teaching Material Based on Science, Environment, Technology, and Society to Improve Student's Critical Thinking Skills: Synchronous and Asynchronous Learning During Covid-19 Pandemic

curriculum content that must be mastered by students with basic competencies to achieve competency standards of each subject in certain educational units.

The use of teaching materials has not become a special concern by the teacher, if the teaching materials are developed according to the needs of students, learning will be achieved properly and fundamentally. One way that is offered is by applying the SETS learning model in teaching materials. Science, Environment, Technology, and Society (SETS) based teaching materials were developed with an emphasis on integration between the four elements, namely; Science, Environment, Technology, and Society. scientific concepts that are realized in the form of technology to facilitate people's work, as well as fix problems by offering environmentally friendly solutions (Khasanah, 2015). Learning with the SETS learning model is very suiTable to be applied to science learning. The SETS learning model makes science learning more interesting, fun, and enjoyable meaningful because students are given the opportunity to gain knowledge not only from books but from take advantage of technology, the environment and society. This will make learning more interesting and interesting fun, so that the knowledge received by students is not quickly forgotten (Widiantini et al., 2017). According to Retno and Marlina (2018) Through the SETS approach students are conditioned to be willing and able to apply scientific principles to produce technology work followed by a thought for reduce or prevent possible impacts negatives that may arise from the appearance of the product this technology for the environment and society.

Learning science in elementary schools related to the environment is an Ecosystem. The Basic Competencies expected in this material are 'Analyze the relationship between ecosystem components and food webs in the surrounding environment. 'SETS-based science teaching materials were developed to strengthen thematic books that have been integrated between subjects, and are used as alternative solutions to improve critical thinking. This teaching material has several advantages, namely formulating the problem so that it breaks down clearly in the student environment so that students can understand and decide what action will be given to a problem. SETS-based science teaching materials contain learning activities that develop local potential in the environment around the school and where students live which can be used as a learning resource so that it allows students to learn independently where students can consider the advantages and disadvantages of using the concept of science. By Kadir's research (2018) SETS used in learning utilizes teaching materials and is very helpful for students in improving understanding of environmental pollution material. This teaching material also fulfills the element of need, which means that this teaching material is needed by students and the demands of the curriculum to support students in improving their critical thinking skills (Hidayaturrohman et al., 2017). Oktaviani et al (2017) stated learning devices with a valid SETS vision, effective, and practically used to improve critical thinking skills.

In accordance with previous research conducted by Nugraha et al (2013) that in the teaching and learning process students begin to be given activities that support their thinking skills, students are faced with daily problems in class and offer several alternative solutions so that students can get used to it. Not only given theoretical material so that students' critical thinking skills improve. According to Lamsihar et al (2020) with an environmental approach, the teacher has applied an environmental 
A Teaching Material Based on Science, Environment, Technology, and Society to Improve Student's Critical Thinking Skills: Synchronous and Asynchronous Learning During Covid-19 Pandemic

approach to increase student stimulus to think critically. Setiyono (2011) stated learning activities with the SETS vision can practice students' critical and creative thinking skill.

\section{RESEARCH METHOD}

\section{General Background}

This research is a type of research and development Research and Development (RnD), which is research that is applied to produce certain products and test the effectiveness of the products produced (Sugiyono, 2016). With the aim of developing a SETS-based science teaching material to improve students' critical thinking. The research design used a 4-D model. This teaching material was developed using the 4-D model (four-D model). Thiagarajan, Semmel (1974) the 4-D model in development research consists of four stages of development, namely: 1) define, 2) design, 3) develop, and 4) disseminate. This method and model were chosen because they were coherent, clear and in accordance with the research objectives to produce a product in the form of SETS-based Natural Science teaching materials.

\section{Sample}

The research subjects for the development teaching materials based SETS were the fifthgrade students of the Manukan Kulon State Elementary School, Tandes District, Surabaya City for the 2020/2021 school year totaling 92 students.

\section{Instrument and Procedures}

This type of research is development research to product development. Development research is used to products and get the effectiveness of the products (Astutik \& Prahani, 2018). The instruments and procedures used in this study were 1) The validation sheet as an assessment given by the validator by giving a check $(\sqrt{ })$; 2$)$ This observation sheet on the implementation of teacher learning and student activities (checklist) is used to obtain data on the practicality of teaching materials in supporting learning activities. The observation sheet will be implemented to teachers and students who contribute to the trial of teaching materials; 3) The student response questionnaire sheet (checklist) is used to obtain data on the effectiveness of teaching materials to improve students' critical thinking skills. Questionnaire sheets will be used to obtain student response data to the benefits of using teaching materials developed to improve students' critical thinking skills; 4) The test sheet includes pre-test and post-test used to measure critical thinking skills as a result of student learning to improve critical thinking skills.

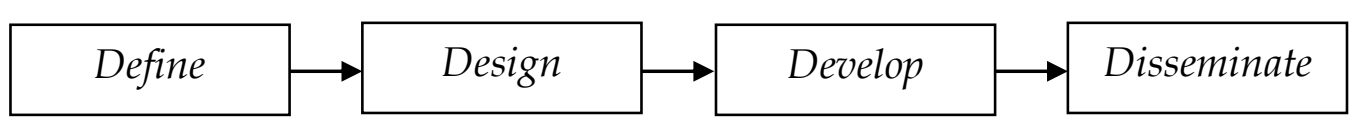

Figure 1. Flowchart Four-D Models.

\section{Data Analysis}

Development data obtained from SETS-based teaching materials that have been validated by media experts and material experts. To determine the appropriateness of the device, the percentage of agreement between validators' opinion is calculated using the percentage of agreement $(\mathrm{R})$, with the formula: 
Information:

$$
\mathrm{R}=\frac{\sum K}{\sum N}
$$

$\mathrm{R}=$ Average

$\mathrm{K}=$ Number of aspects assessed

$\mathrm{N}=$ The total number of aspects

The data analysis on each aspect of the average score is in accordance with the following Table 1 .

Table 1. Learning device assessment criteria.

\begin{tabular}{ccl}
\hline Value Interval & Value Category & \multicolumn{1}{c}{ Information } \\
\hline $3.6 \leq \mathrm{P} \leq 4.0$ & Very Valid & Can be used without revision \\
$2,6 \leq \mathrm{P} \leq 3,5$ & Valid & Can be used with minor revisions \\
$1.6 \leq \mathrm{P} \leq 2.5$ & Less Valid & Can be used with major revisions \\
$1.0 \leq \mathrm{P} \leq 1.5$ & Invalid & Not yet usable \\
\hline
\end{tabular}

The appropriateness of SETS-based Natural Science teaching materials if the average of media and material validation gets $\geq 2.6$ from the Table 1 . Observation data were obtained from observations of teacher and student learning implementation during the implementation of online learning. This observations using the Microsoft Teams Platform which was assessed by the Observer by participating in learning activities in Microsoft Teams to observe the learning process and its obstacles. The result of the observation is in the form of a score using the Likert reference.

Table 2. Observation rating scale.

\begin{tabular}{cc}
\hline Score & Criteria \\
\hline 1 & Not good \\
2 & Pretty good \\
3 & Good \\
4 & Very good \\
\hline
\end{tabular}

(Sugiyono, 2016: 141)

The score obtained from the observation results is then processed using the following formula.

Information:

$$
\mathrm{P}=\frac{\sum K}{\sum N} \times 100 \%
$$

$\mathrm{P}=$ Percentage of implementation

$\mathrm{K}=$ The number of aspects that were implemented

$\mathrm{N}=$ The total number of aspects observed

The percentage of observations is used to determine the implementation of the learning process when using SETS-based science teaching materials. After the percentage results are obtained, they are interpreted based on the following criteria Table 3. 
A Teaching Material Based on Science, Environment, Technology, and Society to Improve Student's Critical Thinking Skills: Synchronous and Asynchronous Learning During Covid-19 Pandemic

Table 3. Learning implementation.

\begin{tabular}{cc}
\hline Score Interval & Rating Category \\
\hline $75 \%-100 \%$ & Well done \\
$50 \%-74 \%$ & Performed pretty well \\
$25 \%-49 \%$ & Not doing well \\
$0 \%-24 \%$ & Not done \\
\hline
\end{tabular}

SETS-based science teaching materials are said to be practical if the average result of the observation of the implementation of learning gets $\geq 75 \%$ of the Table 3 . Student activities are carried out to observe activities carried out by students in the learning process. Student activity observation sheets were carried out by one observer who participated in the Ms. Teams meeting. The data at this stage are described in the form of a percentage.

Information:

$$
\mathrm{P}=\frac{\sum K}{\sum N} \times 100 \%
$$

$\mathrm{P}=$ Percentage of implementation

$\mathrm{K}=$ The number of aspects that were implemented

$\mathrm{N}=$ The total number of aspects observed

The results of the percentage of student activity using the following criteria.

Table 4. Student activities.

\begin{tabular}{cc}
\hline Score Interval & Rating Category \\
\hline $76 \%-100 \%$ & Active \\
$51 \%-75 \%$ & Enough Active \\
$26 \%-50 \%$ & Less Active \\
$0 \%-25 \%$ & Not active \\
\hline
\end{tabular}

(Riduwan, 2013)

Questionnaire data obtained through questionnaires from student responses to SETSbased science teaching materials. The scale of the questionnaire data measurement uses the Guttman scale reference. The Guttman scale is depicted in the following Table 5.

Table 5. Student Questionnaire Rating Scale

\begin{tabular}{cc}
\hline Answer & Score \\
\hline Yes & 1 \\
Not & 0 \\
\hline
\end{tabular}

(Sugiyono, 2016)

The score obtained from the questionnaire results is then processed using the following formula.

$$
P=\frac{\text { Number of students who answered "yes" }}{\text { Total number of students }} \times 100 \%
$$

(Riduwan, 2013) 
A Teaching Material Based on Science, Environment, Technology, and Society to Improve Student's Critical Thinking Skills: Synchronous and Asynchronous Learning During Covid-19 Pandemic

The percentage of the questionnaire was used to determine student responses to SETS-based science teaching materials. After the percentage results are obtained then interpreted based on the following criteria Table 6.

Table 6. Percentage criteria for student questionnaires.

\begin{tabular}{ccc}
\hline No. & Average Score & Category \\
\hline 1. & $0 \%-20 \%$ & Not good \\
2. & $21 \%-40 \%$ & Less good \\
3. & $41 \%-60 \%$ & Pretty good \\
4. & $61 \%-80 \%$ & Good/Worth it \\
5. & $81 \%-100 \%$ & Very Good/Very Worth it \\
\hline
\end{tabular}

(Riduwan, 2013)

SETS-based teaching materials are declared effective if the average of the results of the questionnaire or questionnaire responses to the use of SETS-based science teaching materials gets $\geq 60 \%$ of the percentage criteria Table for the student questionnaire. Analysis of Test Result Data. Research on the development of SETS-based science teaching materials to improve critical thinking skills in the form of quantitative using a one-group pretest - posttest design. The one-group pretest - posttest design pattern is described as follows.

\section{$01 \times 02$}

Information:

(Sugiono, 2016)

$\mathrm{O} 1=$ Score pretest (before treatment)

$\mathrm{X}=$ Treatment which is given

$\mathrm{O} 2$ = Score posttest (after treament)

Analysis of Critical Thinking Ability Data is carried out as a determination of presentation, with the following formula:

$$
\mathrm{M}=\frac{\sum F}{N} \times 100 \%
$$

Information:

M : Students' critical thinking skills

$\sum \mathrm{F} \quad$ : The score obtained by the student

$\mathrm{N} \quad$ : Maximum score

The increase in critical thinking was analyzed by using the gain score (score increase) on the students' scores between the pretest and posttest scores. The amount of increase was analyzed using the formula (Hake, 1999)

$$
<\mathrm{g}>=\frac{\text { Spos-Spre }}{\text { Smax }- \text { Spre }}
$$

(Simbolon, 2015)

Information:

g (gain) : increase students' critical thinking skills

Spre : Pretest Score

Spost : Posttest score

Smax : Maximal score 
A Teaching Material Based on Science, Environment, Technology, and Society to Improve Student's Critical Thinking Skills: Synchronous and Asynchronous Learning During Covid-19 Pandemic

\begin{tabular}{cc}
\multicolumn{2}{c}{ Table 7. Criteria for gain scores. } \\
\hline Limitation & Criteria \\
\hline$<\mathrm{g}>\geq 0.7$ & High Gain \\
$0.7 \geq<\mathrm{g}>\geq 0.3$ & Medium Gain \\
$<\mathrm{g}>\leq 0.3$ & Low Gain \\
\hline
\end{tabular}

(Simbolon, 2015)

Analysis of the completeness of learning outcomes, at this stage to calculate the test data for student learning outcomes the researcher refers to the criteria competency minimum determined by the school, 76. The percentage of student learning completeness as a whole is calculated:

Information:

$$
\mathrm{P}=\frac{\sum K}{\sum N} \times 100 \%
$$

$\mathrm{P}=$ Percentage of implementation

$\mathrm{K}=$ the number who completed studying

$\mathrm{N}=$ total number of students

Completeness of competency attainment indicators was analyzed using qualitative descriptive. An indicator is said to be complete if $\geq 75 \%$ of students have reached the indicator. To calculate the percentage $(\mathrm{P})$ it can be calculated using equations.

\footnotetext{
Percentage of learning objectives completeness

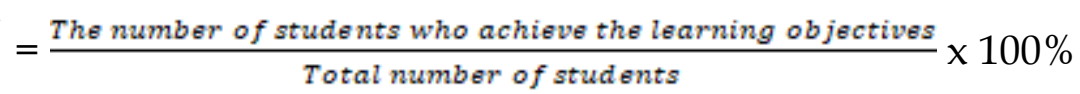

Data analysis in this study used the paired t-test formula to determine the significance of the SETS-based teaching materials developed. Statistical analysis, including parametric statistical tests, must meet the prerequisite tests, namely the normality test and the homogeneity test. The error rate (significance level) used in this study was 0.05. This analysis prerequisite test aims to determine whether there are deviations or not on the existing variables. The normality test in this study used Kolmogorof-Smirnov. To determine whether the distribution of data is normal or not, it can be seen from the magnitude of the Kolmogorov-Smirnov value for each variable to be studied. The test criterion is if the $p$ value is $\geq 0.05$, the data is normally distributed. Conversely, if the $\mathrm{p}$ value is $\leq 0.05$, the data is not normally distributed.

\section{RESULTS AND DISCUSSION}

In this research, several things have been done, namely the development of teaching materials developed according to the needs of teachers who need supporting teaching materials for the use of the SETS approach. The development carried out was the development of SETS-based science teaching materials. Those that are developed to support the development of teaching materials include lesson plans. related to ecosystem cycle materials using the SETS approach, the syllabus, and the main components, namely, SETS-based science teaching materials, ecosystem materials. SETS-based teaching materials are developed according to the skills needed by students, namely critical thinking in dealing with a problem, especially problems in the surrounding environment. 
A Teaching Material Based on Science, Environment, Technology, and Society to Improve Student's Critical Thinking Skills: Synchronous and Asynchronous Learning During Covid-19 Pandemic

This research produces science, Environment, Technology, and Society (SETS) -based science teaching materials that integrate the four elements into their application in everyday life. This teaching material was developed to strengthen thematic books that have been integrated between science subjects and other subjects, and are used as alternative solutions that enhance critical thinking. In this teaching material, it clarifies the problems that occur in the environment concretely and completely so that students can understand and take a position to overcome problems that occur in their daily life. The teaching materials to be developed lead to students' critical thinking skills based on Science, Environment, Technology, and Society (SETS) with exploration, concept development, problem-solving / issue analysis, conceptualization, and assessment. Thus SETS based chemistry teaching materials with local potential is very urgent to be made in order to preserve the values of local knowledge while fostering students' entrepreneurial interest. (Hairida, 2017)

This research was conducted online because of the Covid-19 emergency so that learning in schools was no longer carried out face-to-face. Face-to-face online learning is carried out with the help of the Microsoft Teams. Online face-to-face learning is carried out based on the obligations of students for Study From Home (SFH) in semester 2 starting in March 2020. Learning is carried out synchronously by utilizing the Microsoft Teams application so that teachers and students can ask questions and answers directly and asynchronously (indirectly) in this case the assignment of houses such as project activities, observations, (Assignments: KEGIATAN 12. MEMBUAT KERANJANG TAKAKURA SEBAGAI SOLUSI TEKNOLOGI 1 Due M... posted in Science, Environment, Technology, Society Class / General at Mar 7, 2021 10:38 PM) and critical thinking test questions (http://bit.ly/soalposttestberpikirkritis) using Google Form. The teaching materials used in the research were sent by researchers via Microsoft Teams along with other asynchronous activities.

\section{The Validity of Learning Devices}

The Validity of Science, Environment, Technology, and Society Based Teaching Materials According to Mudlofar (2012) teaching materials are all materials to be used in assisting instructors or teachers in implementing learning in the classroom. The material is in the form of a written or unwritten material. Teaching materials are also interpreted as tools, texts and various information that are used or needed by the instructor / teacher to study and plan in the implementation of learning. Before being used for research, the instruments used were validated first by an expert validator.

Table 8. Results of the validation of research instruments by expert validators.

\begin{tabular}{lcl}
\hline \multicolumn{1}{c}{ Validated instrument } & Average Score & Category \\
\hline Content Feasibility Aspects & 3.40 & Valid \\
Presentation Feasibility Aspects & 3.80 & Very Valid \\
Aspects of Language Feasibility & 3.80 & Very Valid \\
Aspects of Graphic Feasibilitys & 3.70 & Very Valid \\
Overall Average & 3.66 & Very Valid \\
\hline
\end{tabular}

From the results of the validation it can be seen that the teaching materials developed got an average score with a very valid category from the validator as many as 30 aspects from 44 aspects of the assessment and the rest were valid categories in each 
A Teaching Material Based on Science, Environment, Technology, and Society to Improve Student's Critical Thinking Skills: Synchronous and Asynchronous Learning During Covid-19 Pandemic

aspect with an average of 3-4. Regarding the results of the validation of SETS-based science teaching materials as a whole is 3.6 which meets the criteria of $3.6 \leq \mathrm{P} \leq 4.0$ is included in the very valid category because the teaching materials developed are in accordance with the learning activities carried out and meet the national standards of Indonesian education in feasibility aspects in content, presentation, graphics, language, critical thinking assessment. can be categorized as very good qualifications based on the Likert scale reference in determining the criteria for the validation results in this study.

Based on the results of the validity of draft I, there are several scores on the validity instrument that must be corrected according to the validator / expert's suggestion. Then, based on suggestions from the validator, there were also several aspects of the instrument that were corrected. The revision results resulted in draft II and all validators stated that the media was suiTable for use in this research and given to students. The size of a product can be said to be of quality if it has met several aspects of product quality. Products developed in this development research based on the validation test of expert validators have shown that all aspects tested have a product validity score of Very Good. This statement is in accordance with the opinion expressed by Nieveen (1999). Learning tools are said to be good to use if they meet the criteria for feasibility, practicality, and effectiveness (Nieveen, 1999). The learning device developed is declared valid or invalid using an instrument in the form of a validation sheet which will be filled in by an expert in their field called a validator to find out the shortcomings of the device being developed and whether it is suiTable for use in learning activities (Yusuf, 2016).

The SETS-based science teaching materials were declared valid and appropriate according to the validators. The teaching materials used received revisions from the validator, including the use of prepositions, the use of terms along with their meanings, images accompanied by source information, evaluating activities in teaching materials, replacing images that can make students misconceptions, reviewing the definition of the food chain according to the concept SETS elements in one activity. The importance of bringing up activities that are integrated with the four elements of SETS and in accordance with the student's environment is because according to Calado et al (2015) The textbook used is in the sufficient category to improve the complex integration of STSEs, even though there is information that is not relevant in their environment.

\section{The Validity of the Learning Implementation Plan}

In addition to teaching materials, the validators also assessed the lesson plans and syllabus that have been developed to support the development of teaching materials carried out. The intended implementation planning includes the preparation of a learning implementation plans, storage of media and learning resources, learning assessment tools, and learning scenarios. The design of the syllabus and lesson plans being developed must also be adjusted to the learning approach and strategy used.

Table 9. Results of the validation of research instruments by expert validators.

\begin{tabular}{lcc}
\hline Validated instrument & Average Score & Category \\
\hline Identity & 4.00 & Very Valid \\
The SETS approach & 4.00 & Very Valid \\
Learning Facilities and Resources & 4.00 & Very Valid \\
Learning Steps & 3.90 & Very Valid \\
\hline
\end{tabular}


A Teaching Material Based on Science, Environment, Technology, and Society to Improve Student's Critical Thinking Skills: Synchronous and Asynchronous Learning During Covid-19 Pandemic

\begin{tabular}{lcc}
\hline Validated instrument & Average Score & Category \\
\hline Cognitive Aspects & 3.8 & Very Valid \\
Language & 3,7 & Very Valid \\
Overall Average & 3.83 & Very Valid \\
\hline
\end{tabular}

From the results of the validation it show the teaching materials that have been developed by the researcher get an average score with a very valid category from the validator as many as 16 aspects from 18 aspects of the assessment and the rest are categorized as valid. Three validators provide an assessment that the teaching materials developed can be used by revisions. Three validators gave an assessment that the lesson plans in each aspect with an average of 3-4. So the lesson plans developed to support SETS-based science teaching materials are declared valid and appropriate according to the validators with various notes on revision of lesson plans and validators from the validators, namely, raising critical thinking goals, reinterpreting the objectives of each activity, adding variations to provide motivation, namely by providing a picture. According to Akbar (2013), a good lesson plan is according to the following things, including 1) clear learning objectives; 2) material descriptions in accordance with learning objectives, student characteristics, and scientific fields; 3 ) clear and appropriate material organization allocation of time; 4) learning resources according to the learners' cognitive; 5) learning steps are described in detail and describe the approaches, strategies/methods used; 6) learning techniques reflected in the learning steps are in accordance with the objectives to be achieved; 7) completeness of the tools (procedure, type of assessment, assessment instrument and rubric assessment).

\section{Validity of the Syllabus}

The result of the validation of the syllabus developed by the researcher is a Basic Competency with an indicator of the achievement of students' critical thinking skills. The results of the validation of the syllabus by the three validators show the results of the validation assessment in the form of content, language, and time aspects, getting a very valid category as many as 2 very valid category indicators as many as 11 indicators. Based on the syllabus validation score obtained in each aspect, the syllabus validity score got a mode of 3.7 when it was associated with the validation assessment category according to Ratumanan and Laurens (2015) indicating that the syllabus developed was included in the very valid category with slight revisions.

\section{The Validity of the Critical Thinking Test}

Teaching materials and tools developed as an alternative solution to the development of thinking, namely critical thinking skills. After clearly formulating goals, designing and developing learning programs in accordance with the characteristics of students that are easy to achieve and measure. Thus, a critical thinking test for students was also developed. the results of the validation of the test questions that get an average value of all aspects of 3.9 and have met the criteria of $3.6 \leq \mathrm{P} \leq 4.0$ with a description of the aspects: 1) questions according to indicators 2) questions to measure critical thinking 3) clear instructions 4) does not contain a double meaning; 5) EYD appropriate sentences and easy to understand. The revision note from the validator is for question no. 8 and No. 11 it is necessary to match the indicators of critical thinking with the questions, 
A Teaching Material Based on Science, Environment, Technology, and Society to Improve Student's Critical Thinking Skills: Synchronous and Asynchronous Learning During Covid-19 Pandemic

According to Nieveen (1999), apart from being valid, learning tools must also be practical and effective. Not only lesson plans, critical thinking questions must also be valid before they are tested, to obtain practicality data for teaching materials, the teacher's activity observation sheet instrument is used. The teacher believes that observations are made of the implementation of learning in accordance with the lesson plan design and test questions that have been developed and use science-based teaching materials SETS in teaching and learning activities.

\section{Practicality of Science, Environment, Technology, and Society Based Teaching Materials}

The practical assessment of science, environment, technology, and society (SETS) teaching materials in fifth-grade elementary schools was carried out online using the Microsoft Teams application, and Google form this was due to the Covid-19 pandemic and recommendations from the government so that learning was not conducted directly so that researchers do it online, researchers ask observers for help to observe the practicality of SETS-based science teaching materials.

Table 10. Results of learning implementation analysis.

\begin{tabular}{lcc}
\hline \multicolumn{1}{c}{ Rated aspect } & Percentage & Information \\
\hline $\begin{array}{l}\text { Results of Meeting Learning } \\
\text { Implementation 1 (Class A, B, C) }\end{array}$ & $89 \%$ & Well done \\
$\begin{array}{l}\text { Results of Meeting Learning } \\
\text { Implementation 2 (Class A, B, C) }\end{array}$ & $94 \%$ & Well done \\
$\begin{array}{l}\text { Results of Meeting Learning } \\
\text { Implementation 3 (Class A, B, C) }\end{array}$ & $97 \%$ & Well done \\
\hline
\end{tabular}

In learning activities students also carry out activities, to pay more attention to the details of students learning, observers 1 and 2 also observe students' behavior specifically. Of the 3 classes, the average student is active in paying attention to the teacher's explanation, because the class teacher has made it a habit to respect someone who is talking. The teacher also uses feedback in explaining, meaning 2-way communication, involving students in the thought process, so that according to the findings, students will be active if the teacher offers something new that will attract other students' magnets to imitate and follow.

Table 11. Results of student activity analysis.

\begin{tabular}{lcc}
\hline \multicolumn{1}{c}{ Rated aspect } & Percentage & Information \\
\hline $\begin{array}{l}\text { Results of Meeting Student Activities 1 } \\
\text { (Class A, B, C) }\end{array}$ & $91 \%$ & Active \\
$\begin{array}{l}\text { Results of Meeting Student Activities 2 } \\
\text { (Class A, B, C) }\end{array}$ & $96 \%$ & Active \\
$\begin{array}{l}\text { Results of Meeting Student Activities 3 } \\
(\text { Class A, B, C) }\end{array}$ & $98 \%$ & Active \\
\hline
\end{tabular}

The SETS model is quite capable of developing students' cognitive, affective, and psychomotor. According to Yuniastuti (2015) The SETS approach explains that the four main elements of SETS can be mutually exclusive giving in both positive and negative terms. If students are accustomed to paying attention positive and negative association of SETS elements, then their brains will always trying to analyze the conditions and 
A Teaching Material Based on Science, Environment, Technology, and Society to Improve Student's Critical Thinking Skills: Synchronous and Asynchronous Learning During Covid-19 Pandemic

synthesize something new and directed at the acquisition of inner goodness the final step. Learning in schools basically has links with other components outside of the subject itself. As in the process of learning science or natural science, science concepts need to be linked to other components such as the environment, technology, and society. that the development of science with technological advances is interrelated, and affects the social-community life and has an impact on the environment. In SETS learning, teachers and students both have a role which determines the achievement of learning objectives. The teacher's role creates a pattern thinking that sees the future with its various implications, brings learners to always think in an integrated manner, inviting students to think critically inwardly face something by referring to SETS (Yulistiana, 2015). Learning activities with the SETS approach can improve students' problem solving skills because learning activities begin with a problem presentation. Students are required to solve problems in their environment. At the final stage of learning, students are expected to be able to master physics material and solve problems (Usmeldi et al., 2017)

This is also supported by research from Yörük et al (2010) which states that STSE guides students to hone their soft skills. Be brave in researching something related to the environment. So that it allows students to use their skills and knowledge to solve a problem. Research by Nugraha et al (2013) that the teaching materials developed contained a material that connected the materials to be studied with the daily life of students. In teaching materials there are also materials and questions that are able to stimulate students in active student involvement in the learning process. these components which contain the various components of the SETS vision.

\section{The Effectiveness of Science, Environment, Technology, and Society Based Teaching Materials} Student responses are responses given by students after participating in a series of learning processes. Student responses to learning activities using SETS-based teaching materials were obtained using student response questionnaires. Student response questionnaires are given after all learning activities have been carried out. Filling in the response questionnaire sheet is done online via the google form platform. Students are asked to fill out a questionnaire response sheet related to the opinions of each student on the device developed, the learning process, the teaching materials developed, and other supporting components.

Table 12. Student response results.

\begin{tabular}{clccccc}
\hline & & \multicolumn{2}{c}{$\begin{array}{c}\text { Number of students who } \\
\text { answered }\end{array}$} & \multicolumn{2}{c}{ Percentage } & Percentage \\
& Question & Yes & Not & Yes & Not & \\
\hline 1 & Question 1 & 92 & 0 & $100 \%$ & $0 \%$ & Very good \\
2 & Question 2 & 79 & 13 & $86 \%$ & $14 \%$ & Very good \\
3 & Question 3 & 92 & 0 & $100 \%$ & $0 \%$ & Very good \\
4 & Question 4 & 87 & 5 & $95 \%$ & $5 \%$ & Very good \\
5 & Question 5 & 92 & 0 & $100 \%$ & $0 \%$ & Very good \\
6 & Question 6 & 88 & 4 & $96 \%$ & $4 \%$ & Very good \\
7 & Question 7 & 92 & 0 & $100 \%$ & $0 \%$ & Very good \\
8 & Question 8 & 87 & 5 & $95 \%$ & $5 \%$ & Very good \\
9 & Question 9 & 92 & 0 & $100 \%$ & $0 \%$ & Very good \\
10 & Question 10 & 92 & 0 & $100 \%$ & $0 \%$ & Very good \\
11 & Question 11 & 78 & 14 & $85 \%$ & $15 \%$ & Very good \\
\hline
\end{tabular}


A Teaching Material Based on Science, Environment, Technology, and Society to Improve Student's Critical Thinking Skills: Synchronous and Asynchronous Learning During Covid-19 Pandemic

\begin{tabular}{|c|c|c|c|c|c|}
\hline Question 12 & 92 & $\overline{0} 0$ & $100 \%$ & $0 \%$ & Very good \\
\hline Percentage Average & & & $96 \%$ & $4 \%$ & Very good \\
\hline
\end{tabular}

The results showed that learning with SETS-based science teaching materials to improve students' critical thinking skills received a positive response. This can be seen from the average positive responses given by students, the percentage of answering "yes" was between $85-100 \%$ and answering "no" between $0-15 \%$. To measure the effectiveness, the researcher conducted a pretest and posttest. The method of application is before learning the researcher asks students to look for environmental issues in their place of residence, then use it to next day during online learning. In pretest trial process answering critical thinking questions about environmental issues and ecosystem components, students were given a review of material on ecosystem; ecosystem components, the relationship between living things in the ecosystem, the balance of the ecosystem. Then, the researcher gave instructions to students to carry out discovery activities, experimental activities on teaching materials.

The pretest trial was carried out by involving 92 fifth-grade students, ranging from grades A, B, and C of Manukan Kulon State Elementary School. After that the researchers conducted a posttest trial. Before do the Posttest, the researchers provided treatment by testing SETS-based science teaching materials. The application or posttest trial is carried out online using the Microsoft Teams application, this is due to the Covid-19 pandemic and a instruction from the government that learning is online via Microsoft Teams. The students' activities in this study were conducting observations and experiments then sending photos and reports as well as worksheet to the Microsoft Teams Online Class so the teacher could make concrete assignments. Assessment of the results of the pretest and posttest obtained the data below.

Table 13. Student critical thinking test results.

\begin{tabular}{clccc}
\hline & \multirow{2}{*}{ Score } & \multicolumn{2}{c}{ Learning outcomes } & \multirow{2}{*}{ Pretest } \\
Posttest & Information \\
\hline 1 & Lowest Value & 40 & 83 & \\
2 & The highest score & 69 & 100 & \\
3 & Classical Completeness & $25 \%$ & $95 \%$ & \\
4 & Average & 65.62 & 89.82 & High \\
\hline
\end{tabular}

Analysis of critical thinking test results using N-Gain. N-Gain is used to calculate the magnitude of the increase in critical thinking skills. Based on Table 14, information is obtained that the average score of critical thinking skills achieved by the test class students after the pretest on indicator 1 is 72.6, indicator 2 is 69.2, indicator 3 is 60.9, indicator 4 is 59.6. Meanwhile, based on the posttest score, there is an increase in the average value of critical thinking skills on indicator 1, namely 94.6, indicator 2 of 91.3, indicator 3 of 89.1, and indicator 4 of 84.1. The increase in Critical Thinking ability can be seen from the N-Gain test score of Critical Thinking ranging from 0.7 to 1 . The NGain mode test results for students' Critical Thinking of the tryout class were in the high category, as indicated by the increase in the scores on the pretest and posttest.The results of the critical thinking skills test of students in the pretest and posttest shows that the critical thinking skills of students obtained after being given treatment with 
A Teaching Material Based on Science, Environment, Technology, and Society to Improve Student's Critical Thinking Skills: Synchronous and Asynchronous Learning During Covid-19 Pandemic

SETS-based science teaching materials with the results of the N-Gain calculation show $0.35-1.00$ with a gain classification according to Hake (1999). people with a percentage of $39.13 \%$ and in the high category were 56 people with a percentage of $60.87 \%$. The increasing number of students' critical thinking test results is supported by research by Maimunah (2016). The difference in the development of critical thinking skills experienced by students after the learning process is because the SETS stage is full of thinking, arguing, and discussion activities. The three stages are in the SETS stage. These students' abilities cannot be separated from the active role of students in seeking information to be applied in solving problems. This is in accordance with the opinion of Sari and Sugiyarto (2015) that students need to be accustomed to critical thinking so that it can be used in problems and problems that will enter into everyday life, one of which is through the use of learning media that can improve students' critical thinking skills. The concept application stage of students uses the concepts that have been learned in their daily lives. The conceptualization stage of students corrects wrong concepts if misconceptions still occur. In the introductory stage, students are presented with issues that occur in everyday life so that they can explore the knowledge contained in them. The concept formation stage of students gradually reconstructs the concept until they find the right concept. The concept application stage of students uses the concepts that have been learned in their daily lives. The stage of strengthening the concept of students corrects wrong concepts if misconceptions still occur (Hayati et al., 2019).

According to the results of the analysis using $\mathrm{N}$-gain shows an increase in the academic value of 92 students, no students are in the low category, 36 students are in the medium category, and 56 students are in the high category. The average increase in academic scores before learning and after learning using $\mathrm{N}$-gain was 0.8 , with the high category. In accordance with the statement of Trianto (2014), a class can be said to have finished learning classically, if in the class there are $\geq 75 \%$ of students who experience completeness. The average classical completeness result from class A is $93 \%$, Class B $91 \%$, and class C is $93 \%$, so it can be said that SETS-based science teaching materials can improve critical thinking skills. Suprijono (2016: 37) explains that someone who has critical thinking will be useful in dealing with the problems encountered. This indicates that critical thinking is very useful in increasing the ability to make decisions. The results of the normality test of several variables in this study can be seen in the following Table 14.

Table 14. Normality test results.

\begin{tabular}{lcc}
\hline \multicolumn{1}{c}{ Variable } & Significance $\mathbf{( p )}$ & Information \\
\hline Critical Thinking Skills (pretest) & 0.098 & Normal \\
Critical Thinking Skills (posttest) & 0.066 & Normal \\
\hline
\end{tabular}

Based on this Table 14, the results of the normality test can be seen that the significance value for all data on each variable in the study obtains a value greater than 0.05 , so all data is declared to be normally distributed. To perform the homogeneity test, it can be done using the Levene's test, by looking at the significance level of the calculated Levene value. If the Levene value shows a significance level of more than 0.05 , it can be said that there is no difference in variance between sample groups or in other words the variance between groups is the same. The results of the homogeneity test can be seen in the following Table 15. 
A Teaching Material Based on Science, Environment, Technology, and Society to Improve Student's Critical Thinking Skills: Synchronous and Asynchronous Learning During Covid-19 Pandemic

Table 15. Homogeneity test results.

\begin{tabular}{cccc}
\hline Variable & Levene & Score Significance & Information \\
\hline Critical Thinking Skills (pretest) & 1.308 & 0.287 & Homogeneous \\
Critical Thinking Skills (posttest) & 0.647 & 0.531 & Homogeneous \\
\hline
\end{tabular}

Based on this Table 15, the homogeneity test of pretest critical thinking skills shows a value of 0.287 which means greater than 0.05 , while the homogeneity test on posttest critical thinking skills shows a value of 0.531 which means greater than 0.05 . From the overall data, it can be said that there is no difference in variance between sample groups or in other words the variants between groups are the same or homogeneous. The prerequisite test results of the parametric statistical test consisting of the normality distribution test and the homogeneity test have met, so that the next stage of the analysis can be carried out. After testing the prerequisite analysis, the next step is to analyze the data. The data analysis technique used in this study was the paired $t$ test. Because the variables of cognitive ability and emotional social intelligence meet the assumptions of normality and homogeneity, the paired $t$ test is used to determine the significance of the product that has been developed.

Table 16. Results of the test of the effectiveness of SETS-based teaching materials on critical thinking skills.

\begin{tabular}{ccl}
\hline $\mathbf{t}_{\text {count }}$ & Sig. (p) & \multicolumn{1}{c}{ Information } \\
\hline 19,078 & 0,000 & $\begin{array}{l}\text { There is a significant difference between pretest } \\
\text { and posttest }\end{array}$ \\
\hline
\end{tabular}

The calculation using the significance test for the value of students' critical thinking skills in this study obtained tcount of 19.078 with a significant of 0.000 . So, it can be concluded that the significance value $(0.000)<0.05$. Thus, it can be stated that there are significant differences in students' critical thinking skills using the developed SETSbased teaching materials. In the teaching materials, they provide problems that will be solved and are directly related to their daily lives, such as critical thinking exercises by presenting issues that are appropriate to their environment and the task of projects to purify peat water in their environment. The relationship of relevance and problem giving that is directly related to everyday life can make students actively involved in real situations which, if able to attract their attention, can cause students to better understand what they are learning and trying to solve (Rasmawan, 2020). To find out the effectiveness of teaching materials, also use the observation of critical thinking skills. In addition, the observation of students' responses to the effectiveness of teaching materials also uses pretest and posttest to obtain data on the effectiveness of teaching materials.

The results of the pretest and posttest are carried out online via the google form platform. The pretest was carried out before learning using SETS-based science teaching materials. The pretest and posttest used descriptive questions with different questions but with the same weight and indicators. The criteria competency minimum used is 76 because it is adjusted to the criteria competency minimum used by the school. This is in accordance with what was said by Asmuni et al (2019) SETS model directly related to the application of science knowledge to tackle problems with linked technology and society. Model SETS is closely related to students' critical thinking skills. Teachers can 
A Teaching Material Based on Science, Environment, Technology, and Society to Improve Student's Critical Thinking Skills: Synchronous and Asynchronous Learning During Covid-19 Pandemic

link science concepts taught with problems that occur in society and the everyday environment so as to help students apply learning outcomes at school in their daily lives (Afifah et al., 2014).

The implementation of the SETS approach in learning is expected to encourage students to seek and form their own knowledge in the surrounding environment and then apply it in everyday life to solve problems that occur. The assessment stage is carried out by the teacher to evaluate the students' abilities and the learning process that has been carried out. This is in accordance with the objectives of implementing SETS, namely to improve process skills, pedagogical knowledge, epistemological views, scientific knowledge, civic behavior and decision making (Chowdhury, 2016). Amanda et al (2018) argue that the ability to think critically is the ability to think to define, formulate, argue, and educate and induce to decide a problem. Based on this, it can be seen that critical thinking enables students to utilize intellectually by thinking rationally both through observation, analysis and the use of reason in decision making.

This problem-solving ability is developed at each stage of the SETS, namely through the emergence of problem issues at the preliminary stage, based on the problems presented then students are encouraged and motivated to give / answer questions. The questions given by the students were then used as further interactions. After that students carry out an investigative task in the research group, then present the results of the study (Maimunah, 2016). According to Lamsihar et al (2020) with an environmental approach, teachers have applied an environmental approach to increase student stimulus to think critically, so students are interested in critical thinking. Students have paid attention to the classroom environment inside and outside the classroom before, during the learning process and after the learning process. As students progress into junior and senior high school, critical thinking skills, decision-making skills, and information gathering skills need to be taught. The individual must also be skilled at evaluating the future consequences of their present actions and the actions of others. Changwong et al (2018).

In science learning ecosystem material using the SETS model, educators use the discussion method to stimulate (stimulate) and trigger (foster) the enthusiasm for learning because in it there is an interaction process that will foster new knowledge after the exchange of ideas or experiences of students regarding knowledge that is it has. Increase students' understanding and stimulate critical thinking skills, educators use direct observation methods of objects related to the subject matter. Increased understanding of students' concepts with SETS learning is in accordance with research that has examined the consequences of Akcay \& Akcay's SETS learning (2015). The SETS model is directly related to the application of science to solve problems connected with technology and society.

\section{CONCLUSIONS}

Based on the results of the research and discussion previously described, the following conclusions can be drawn: teaching materials developed in science subjects in elementary schools based on science, environment, technology, and society (SETS) have appropriate criteria to improve critical thinking skills in terms of validity. Valid is reflected in the results of the expert validator's assessment, all validators stated that teaching materials based on material, construct, and language are valid. Practical based on the percentage of the implementation of learning with the very good category and 
A Teaching Material Based on Science, Environment, Technology, and Society to Improve Student's Critical Thinking Skills: Synchronous and Asynchronous Learning During Covid-19 Pandemic

the results of student activities are categorized as active. Effective based on the $\mathrm{N}$-gain value in the high category and the paired t-test, the t-test obtained significant value. Pretest and posttest tests as measuring tools to measure students' critical thinking skills. Each individual has different abilities so that the pretest and posttest questions will make it easier for students to increase their interest in learning, especially in critical thinking skills. Indicators of students' critical thinking skills are providing simple explanations, building basic skills, providing more specific explanations, and arranging strategies and tactics. Suggestions for future researchers that critical thinking skills require an appropriate time allocation in implementing the SETS model, in order to obtain maximum results. In addition, SETS learning can be used as an alternative choice for teachers or educators to convey concepts in material other than ecosystems or even in subjects other than science. Based on the results of the analysis, and the findings of the research results, it can be concluded that the science, environment, technology and society (SETS) model of science learning tools is feasible (Valid, Practical, Effective) to use and improves students' critical thinking skills.

\section{REFERENCES}

Afifah, R., Rusilowati, A., \& Supriyadi. (2014). Keefektifan model pembelajaran guided discovery dengan media question cards bervisi SETS dalam membelajarkan kebencanaan alam terintegrasi dalam IPA. Unnes Physic Education Jurnal, 3(1), 6-11. doi.org/10.15294/upej.v 3i1.3099

Akbar, S. (2013). Instrumen perangkat pembelajaran. Bandung: Rosdakarya.

Akcay, B., \& Akcay H. (2015). Effectiveness of science-technology-society (STS) instruction on student understanding of the nature of science and attitudes toward science. International Journal of Education in Mathematics Science and Technology, 3(1), 37-45.

Amanda, S., Muharrami, L. K., Rosidi, I., \& Ahied, M. (2018). Peningkatan kemampuan berpikir kritis siswa pada pembelajaran ipa menggunakan model pembelajaran berbasis masalah yang berbasis SETS. Journal of Natural Science Education Research, 1(1), 57-64.

Asmuni., Sarwanto., \& Masykuri, M. (2019). Pengembangan modul IPA terpadu SMP/MTs kelas VIII berbasis SETS untuk meningkatkan kemampuan berpikir kritis siswa pada tema makanan dan kesehatan tubuh. SPEKTRA: Jurnal Kajian Pendidikan Sains, 5(1), 30-43.

Astutik, S., \& Prahani, B. K. (2018). The practicality and effectiveness of collaborative creativity learning (ccl) model by using PhET simulation to increase students' scientific creativity. International Journal of Instruction, 11(4), 410-424. doi.org/10.12973/iji.2018.11426a

Calado, F. M., Scharfenberg, F. J., \& Bogner, F. X. (2015). To what extent do biology textbooks contribute to scientific literacy? Criteria for analysing science-technology-societyenvironment issues. Education Science, 5(4), 255-280. doi.org/10.3390/educsci5040255

Changwong, K., Sukkamart, A., \& Sisan, B. (2018). Critical thinking skill development analysis of a new learning management model for thai high school. Journal of International Studies, 22(2), 37-48. doi.org/10.14254/2071-8330.2018/11-2/3

Chowdhury, M. A. (2016). The integration of science technology society/science technology society environment and socio scientific issues for effective science education and science teaching. Electronic Journal of Science Education, 20(5), 19- 38.

Firdaus, F. Z., Suryanti, S., \& Azizah, U. (2020). Pengembangan multimedia interaktif berbasis pendekatan SETS untuk meningkatkan kemampuan berpikir kritis siswa sekolah dasar. Jurnal Basicedu, 4(3), 681-689. doi.org/10.31004/basicedu.v4i3.417

Hairida. (2017). Using learning Science, Environment, Technology, and Society (SETS) local wisdom and based colloids teaching material. Journal of Education Teaching and Learning, 2(1), 84-89. doi.org/10.26737/jetl.v2i1.146 
A Teaching Material Based on Science, Environment, Technology, and Society to Improve Student's Critical Thinking Skills: Synchronous and Asynchronous Learning During Covid-19 Pandemic

Hake, R. R. (1999). Analyzing change/gain scores. Woodland Hills: Dept. of Physics, Indiana University.

Hayati, I. A., Rosana, D., \& Sukardiyono, S. (2019). Pengembangan modul potensi lokal berbasis SETS untuk meningkatkan keterampilan proses IPA. Jurnal Inovasi Pendidikan IPA, 5(2), 248-257. doi.org/10.21831/jipi.v5i2.27519

Hidayaturrohman, R., Lesmono, A. D., \& Prihandono, T. (2017). Pengembangan bahan ajar interaktif fisika berwawasan SETS untuk meningkatkan kemampuan berpikir kritis siswa. Prosiding Seminar Nasional Pendidikan Fisika, 1(1), 1-9.

Kadir, A. (2018). Pengembangan bahan ajar IPA berbasis SETS pada siswa MTsN 1 Kendari. AlIzzah: Jurnal Hasil-Hasil Penelitian, 12(2), 1-24. doi.org/10.31332/ai.v12i2.638

Khasanah, N. (2015). SETS (Science, Environmental, Technology and Society) sebagai pendekatan pembelajaran IPA modern pada kurikulum 2013. Seminar Nasional Konsevasi dan Pemanfaatan Sumber Daya Alam, 1(1), 270-277.

Lamsihar, P., Sapriya., \& Komalasari, K. (2020). Development of critical thinking ability through sets based learning approach: An action research on grade XI IPA 1 SMAN 5 Dumai. Journal of International Conference Proceedings, 3(1), 136-149. doi.org/10.32535/jicp.v2i4.788

Maimunah. (2016). Penggunaan model pembelajaran Science, Environment, Technology, and Society (SETS) untuk meningkatkan kemampuan berpikir kritis dan sikap ilmiah. Jurnal Formatif, 6(2), 134-140. doi.org/10.30998/formatif.v6i2.947.

Muakhirin, B. (2014). Peningkatan hasil belajar IPA melalui pendekatan pembelajaran inkuiri pada siswa SD. Jurnal Ilmiah Guru COPE, 1 (18), 51-57.

Mudlofar, A. (2012). Application of curriculum development of education unit level and teaching material in islamic education. Jakarta: Rajawali Pers.

Nieveen, N. (1999). Prototyping to reach product quality. In T. Plomp, N. Nieveen, K. Gustafson, R.M. Branch, \& J. Van (Eds.), Design Approaches and Tools in Education and Training. London: Kluwer Academic Publisher.

Nugraha, D. A., Binadja, A., \& Supartono. (2013). Pengembangan bahan ajar reaksi redoks bervisi SETS, berorientasi konstruktivistik. Journal of Innovative Science Education, 2(1), 2734.

Nur, M., Nasution, S., \& Suryanti. (2013). Berpikir kritis. Surabaya: Universitas Negeri Surabaya Penelitian Unggulan Perguruan Tinggi.

Oktaviani, P., Hartono., \& Marwoto, P. (2017). Pengembangan multimedia interaktif bervisi SETS sebagai alat bantu model Problem Based Learning (PBL) dalam pembelajaran IPA di SMP untuk meningkatkan kemampuan berpikir kritis dan keterampilan sosial peserta didik. PSEJ (Pancasakti Science Education Journal), 2(2), 125. doi.org/10.24905/psej.v2i2.746

Rasmawan, R. (2020). Development of SETS-based teaching materials in acid-base accompanied by critical thinking exercises and moral forming. EduChemia: Jurnal Kimia dan Pendidikan, 5(2), 134-152. doi.org/10.30870/educhemia.v5i2.7934

Ratumanan, T. G., \& Laurens, T. (2015). Penilaian hasil belajar pada tingkat satuan pendidikan. Yogyakarta: Pensil Komunika.

Retno, R. S., \& Marlina, D. (2018). Implementasi SETS (Science, Environment, Technology, and Society) pada pembelajaran IPA SD berbasis inquiry terhadap berpikir ilmiah siswa kelas 4 MI Al-Irsyad Madiun. BIO-PEDAGOGI: Jurnal Pembelajaran Biologi, 7(2), 54-58.

Riduwan. (2013). Skala pengukuran variabel-variabel penelitian. Bandung: Alfabeta.

Sari, D. S., \& Sugiyarto, K. H. (2015). Pengembangan multimedia berbasis masalah untuk meningkatkan motivasi belajar dan kemampuan berpikir kritis siswa. Jurnal Inovasi Pendidikan IPA, 1(2), 153-166. 689. doi.org/10.21831/jipi.v1i2.7501

Setiyono, F. P. (2011). Pengembangan perangkat pembelajaran kimia kelarutan dan hasil kali kelarutan (Ksp) dengan pendekatan SETS untuk meningkatkan kemampuan berpikir kritis dan kreatif siswa. Jurnal Penelitian Pendidikan, 1(2), 149-158. 
A Teaching Material Based on Science, Environment, Technology, and Society to Improve Student's Critical Thinking Skills: Synchronous and Asynchronous Learning During Covid-19 Pandemic

Simbolon, E. R., \& Fransisca. (2015). Pengaruh pembelajaran berbasis masalah dan pembelajaran kontekstual terhadap berpikir kritis siswa SMP. Edusains, 7(1), 97-104. doi.org/10.15408/es.v7i1.1533

Sugiyono. (2016). Metode penelitian kuantitatif, kualitatif dan RED. Bandung: PT. Alfabet.

Suprijono, A. (2016). Cooperative larning: Teori dan aplikasi paikem. Yogyakarta: Pustaka Pelajar.

Susanto, A. (2016). Teori belajar dan pembelajaran. Jakarta: Prenada Media Group.

Syofyan, H., Zulela., \& Sumantri, M. S. (2019). Pengembangan awal bahan ajar IPA di sekolah dasar. Jurnal Pendidikan Dasar, 10(1), 52-67. doi.org/10.21009/JPD.010.06.

Thiagarajan, S., Semmel, D.S., \& Semmel, M.I. (1974). Instructional development for training teacher of exceptional children. Bloomington Indiana: Indiana University.

Trianto. (2014). Mendesain model pembelajaran inovatif, progresif dan kontekstual. Jakarta: Prenadamedia Group

Usmeldi., Amini, R., \& Trisna, S. (2017). The development of research-based learning model with science, environment, technology, and society approaches to improve critical thinking of students. Jurnal Pendidikan IPA Indonesia, 6(2), 318-325. doi.org/10.15294/jpii.v6i2.10680.

Widiantini, N. N. A. S., Putra, M., \& Wiarta, I. W. (2017). Model pembelajaran SETS (Science, Environment, Technology, Society) berbantuan virtual lab berpengaruh terhadap kompetensi pengetahuan IPA. Journal of Education Technology, 1(2), 141-148. doi.org/10.23887/jet.v1i2.11776

Yörük, N., Morgil, I., \& Seçken, N. (2010). The effects of science, technology, society, environment (STSE) interactions on teaching chemistry. Natural Science, 2(12), 1417-1424. doi.org/10.4236/ns.2010.212173.

Yulistiana. (2015). Penelitian pembelajaran berbasis SETS (Science, Environment, Technology, and Society) dalam pendidikan sains. Formatif: Jurnal Ilmiah Pendidikan MIPA, 5(1), 76-82. doi.org/10.30998/formatif.v5i1.169.

Yuniastuti, E. (2015). Pengaruh model pembelajaran SETS (Science, Environment, Technology and Society) terhadap hasil belajar biologi siswa kelas VII SMP Kartika V-1 Balikpapan tahun pelajaran 2015/2016. Jurnal Sains Terapan, 2(1), 72-78. doi.org/10.32487/jst.v1i2.94

Yusuf, M. (2016). Pengembangan perangkat pembelajaran IPA berbasis keterampilan proses untuk meningkatkan keterampilan berpikir kritis siswa sekolah dasar. Tesis. Surabaya: Universitas Negeri Surabaya.

\footnotetext{
*Aziza Syaila Amilyana, M.Pd. (Corresponding Author)

State University of Surabaya

Postgraduate Program, Primary Education Study Program

Continuing Program Development, jl. Unesa Lidah Wetan, Surabaya, Indonesia

Email: syailaamilyana@gmail.com
}

Prof. Dr. dr. Tjandra Kirana M. S. Noer, M.S., Sp. And.

State University of Surabaya

Postgraduate Program, Science Education Study Program

Continuing Program Development, j1. Unesa Lidah Wetan, Surabaya, Indonesia

Email: tjandrakirana@unesa.ac.id

\section{Dr. Raharjo, M.Si.}

State University of Surabaya

Postgraduate Program, Science Education Study Program

Continuing Program Development, jl. Unesa Lidah Wetan, Surabaya, Indonesia

Email: raharjo@unesa.ac.id 